\title{
BUY BRITISH LAST
}

\author{
Mohd Afendi Daud
}

\begin{abstract}
Many scholars who have written on the Buy British Last policy have not discussed it in greater depth, and the issue itself does not seem to be getting anymore attention lately. Prior to the execution of the policy, Malaysia and Britain were already entangled with a number of controversies that severed economic relations between the two countries. This bilateral tension worsened when former Malaysian Prime Minister Dr. Mahathir Mohammad, in retaliation for aggravations over exorbitant student fees at British universities, announced the Buy British Last policy in 1981. The article has two major concerns in this regard: to explore the rationale of the policy and; to comprehend Malaysia's exercise of diplomatic protest as a retaliatory measure against Britain's unfair treatment. Consequently, the British had to send diplomatic mission to Malaysia to resolve the issue. It is also worthwhile to note that surmounting preassures compelled Britain to compromise with Malaysia in order to normalize relations, as the policy was detrimental to both countries. In spite of the fact that the matter was eventually resolved, the Malaysia-Britain relation has been fundamentally changed and was never to be the same again. This article, therefore, also examines how Dr. Mahathir had reshaped Malaysia's diplomatic ties with Britain, to the extent that the former colonizer was no longer accorded favorable treatment. Briefly, it deals with events leading to the announcement of the Buy British Last policy, its rationale and process of implementation, as well as the overall impact of the measure.
\end{abstract}

\section{Pengenalan}

Kebanyakan kajian dan penyelidikan yang dilakukan terhadap dasar luar Malaysia hanya sekitar seorang pemimpin sahaja atau antara beberapa pemimpin dan ada yang hanya mengikut kronologi atau sesuatu tempoh hubungan luar itu dilaksanakan. Tiada satu pun kajian atau penyelidikan yang menumpukan atau menfokuskan polisi Buy British Last (BBL) semasa era pentadbiran Dr. Mahathir. Terdapat hanya sedikit sahaja yang membincangkan topik ini dan kebanyakan artikel atau jurnal yang ditulis hanya mengambil beberapa isu sahaja. Terdapat juga artikel-artikel ${ }^{1}$ dalam jurnal yang menyentuh polisi BBL tetapi masih tiada yang menjuruskan dan memberi fokus kepada BBL. J. Saravanamuttu, ${ }^{2}$ menulis tentang dasar luar Malaysia dengan ASEAN, bermula daripada Tunku Abdul Rahman sehinggalah kepada Dr. Mahathir. Hanya melihat peranan tiap-tiap Perdana Menteri dalam melaksanakan hubungan dengan ASEAN. Oleh itu, kajian ini turut tidak memberi fokus kepada BBL.

Begitu juga dengan artikel-artikel dalam buku ${ }^{3}$ yang diterbitkan dan ada menyentuh hubungan luar Malaysia tetapi masih tiada yang mengkaji hubungan Malaysia-Britain secara lebih khusus lagi. J. Saravanamuttu juga turut menulis dalam artikel bertajuk 'Iconoclasm and Foreign Policy - The Mahathir Years' yang menyentuh dasar luar Malaysia semasa era pentadbiran Dr. Mahathir dan tentang hubungan Malaysia-Britain tetapi terlalu ringkas. Beliau lebih memberi tumpuan kepada Dasar Pandang ke Timur, Hubungan Selatan-Selatan, Politik Muslim dan Kegagalan International Monetary Fund (IMF). ${ }^{4}$ Roger Kershaw ${ }^{5}$ dalam artikelnya menyentuh hubungan luar Malaysia-Britain dalam era pentadbiran Dr. Mahathir 
dan ada menyentuh polisi BBL tetapi tidak menyentuhnya sebagai satu kajian yang lebih mendalam. Beliau hanya memaparkan isu yang berlaku pada tahun 1981 hingga 1983. Lee Poh Ping pula dalam artikelnya yang berjudul 'The Look East Policy, The Japanese Model and Malaysia' ada menyentuh tentang BBL tetapi secara ringkas dan penumpuan lebih kepada hubungan Malaysia-Jepun. ${ }^{6}$ Begitu juga dengan Khadijah Md Khalid dalam artikelnya yang bertajuk 'Malaysia-Japan relations under Mahathir: 'Turning Japanese"?' turut menyentuh secara ringkas sahaja sebagai pengenalan dalam artikelnya yang seterusnya memberikan tumpuan kepada hubungan Malaysia-Jepun. ${ }^{7}$ Rusdi Omar dan Muhammad Afifi Abdul Razak pula turut menulis artikel bertajuk 'Dasar Luar Malaysia dalam konteks hubungan Malaysia-Jepun' memaparkan hubungan Malaysia-Britain secara ringkas dan memberi tumpuan kepada perkembangan hubungan Malaysia Jepun sejak zaman Tunku lagi. Dalam artikel tersebut mereka ada menyatakan bahawa hubungan Malaysia-Britain yang kurang baik semasa pentadbiran Dr. Mahathir adalah sebagai salah satu faktor ${ }^{8}$ Dr. Mahathir telah memperkenalkan Dasar Pandang ke Timur. ${ }^{9}$ Oleh itu penulisan ini juga tidak dapat memberi gambaran sebenarnya isu BBL.

Penyelidik sendiri telah melakukan kajian yang bertajuk 'Dasar Luar Malaysia ke atas Britain: Perbandingan di antara era Tunku Abdul Rahman dengan Tun Dr. MahathirMohamad, 10 namun penyelidik merasakan kajian ini tidak mencukupi untuk menggambarkan keadaan sebenarnya polisi secara terperinci dan lebih komprehensif. Penyelidik merasakan perlunya satu pendekatan kajian yang khusus dan lebih memberi fokus kepada BBL.

Selepas tiga bulan, Dr Mahathir memegang jawatan Perdana Menteri Malaysia telah membuat kejutan dengan mengisytiharkan Buy British Last(BBL). ${ }^{11}$ Berbagai isu telah timbul dan hubungan Malaysia dengan Britain mula renggang. Ada sarjana yang berpendapat kenaikan yuran pengajian di Britain telah menyemarakkan lagi hubungan Malaysia dengan Britain. Dr. Mahathir melihat isu kenaikan yuran pengajian di Britain adalah sikap Britain yang tidak menghargai sumbangan terhadap ekonomi Britain melalui yuran dan perbelanjaan pelajar di Britain. ${ }^{12}$ Bagi Roger Kershaw BBL adalah semi-boikot oleh Malaysia terhadap Britain kerana kenaikan yuran bagi pelajar luar negara tetapi dikecualikan kepada pelajarpelajar dari Komuniti Ekonomi Eropah dan juga kenyataan daripada Suruhanjaya Tinggi Britain, William Bentley yang menyatakan Malaysia patut menghargai pengorbanan yang telah dilakukan oleh pihak Britain dalam sejarah Malaysia bukan sahaja dari segi kewangan tetapi nyawa dan darah bagi menjamin Malaysia menikmati kemerdekaan dengan aman dan stabil. ${ }^{13}$ Tambahan pula kegagalan dalam memohon rayuan daripada pihak Britain untuk mendapatkan pengecualian atau bantuan dari Britain telah membuat hubungan bertambah tegang di antara kedua-dua negara. ${ }^{14}$

Dr. Mahathir telah mengambil tindakan yang begitu drastik ${ }^{15}$ dengan melaksanakan BBL dan menyebabkan hubungan luar yang paling teruk diterima oleh pihak Britain. ${ }^{16}$ Ia adalah rentetan beberapa isu penting yang telah lama dilalui oleh Malaysia terutama soal perlaksanaan Dasar Ekonomi Baru. Khoo Boo Teik menyatakan: "Buy British Last policy was Mahathir's act of retaliation coming after a series of frustrations at British attitudes towards Malaysia."17 Artikel ini mengkaji rasional disebalik pengenalan BBL, proses perlaksanaan, reaksi diplomatik dan kesan dari perlaksanaan BBL.

\section{Pengumuman BBL dan Rasionalnya}

Sebelum Dr. Mahathir memegang tampok pemerintahan lagi pihak Britain telah mendapat layanan yang istimewa terutama dalam proses pemilihan kontrak dan selalunya berjaya mendapatkan kontrak yang ditenderkan. Keistimewaan yang diperolehi oleh Britain tidak lagi seperti masa lalu. Dr. Mahathir mahu keadilan dalam proses pemilihan kontrak bagi menarik lebih ramai lagi pelabur melabur di Malaysia. Walaupun Malaysia mempunyai hubungan 
istimewa dan bersejarah dengan Britain, sikap bias terhadap negara lain perlu . Ghazali Shafie menjelaskan: "he wants to make sure that, that 'bias for' element wasn't there..."18

Perlaksanaan BBL adalah sebagai objektif jangka pendek bertujuan untuk mengubah sikap dan lagak Britain yang selama ini tidak menghiraukan cita-cita dan aspirasi Malaysia; ${ }^{19}$ dan dari segi politik, objektif utama Malaysia adalah ke arah pencapaian kerjasama serantau dan dari itu perhatian dan keutamaan adalah lebih diberi kepada negara-negara ASEAN, negara-negara Islam (OIC), negara-negara berkecuali (NAM) dan negara-negara Komanwel. ${ }^{20}$ Britain tidak diberi keutamaan lagi tetapi hubungan di antara kedua-dua buah negara masih diteruskan. Firdaus Abdullah menjelaskan: "He declared 'Buy British Last' policy as a retaliation to the unfriendly British attitude that adversely affected Malaysia. ${ }^{21}$

BBL dilaksanakan bertujuan untuk memberitahu kepada pihak Britain bahawa Malaysia tidak lagi boleh diperkecilkan dan telah menjadi satu tamparan kepada pihak Britain supaya menghormati Malaysia sebagai sebuah negara yang telah lama merdeka. Ia juga secara tidak langsung telah memerdekakan Malaysia daripada belenggu penjajah dan menjadikan Malaysia sebagai sebuah negara yang telah merdeka, berpendirian sendiri dan bebas dari mana-mana pengaruh. ${ }^{22}$

Bagi Ahmad Atory Hussain, perlaksanaan BBL adalah sesuatu yang dapat menyedarkan pihak Britain dan perlunya pihak Britain merasa sensitif terhadap perubahan yang telah berlaku di Malaysia. Malaysia telah lama merdeka dan pihak Britain perlu menghormati Malaysia dan mengikis sikap kolonialisme. Walaupun selama ini Malaysia telah memberi layanan istimewa kepada Britain tetapi menerima balasan yang kurang baik daripada pihak Britain. ${ }^{23}$ Beliau juga berpendapat tindakan Dr. Mahathir melaksanakan BBL adalah satu tindakan yang radikal tetapi amat sesuai dan tepat masanya. ${ }^{24}$ Musa Hitam mengkritik tindakan Mahathir secara radikal dan mengambil masa yang singkat. ${ }^{25}$

Tindakan Dr. Mahathir ini dianggap berani dan mengikut perubahan waktu. Kebergantungan terhadap Britain telah mula direnggangkan sejak zaman Tun Razak lagi melalui konsep ASEAN dan ZOPFAN. Tun Razak telah memecah tradisi hubungan luar Malaysia dengan mengadakan hubungan diplomatik dengan negara China. Perubahan yang dilakukan walau bagaimanapun tidak memberi kesan secara langsung kepada hubungan Malaysia dengan Britain. Walaupun terdapat masalah dalam hubungan Malaysia dengan Britain ia dapat diselesaikan dengan baik kerana hubungan yang dijalinkan dengan suasana persahabatan yang lama terjalin dan bertolak ansur. ${ }^{26}$ Berbeza dengan Dr. Mahathir yang telah bertindak dengan lebih agresif dan berani. Ramai sarjana yang berpendapat bahawa tindakan berani Mahathir tidak dapat dipengaruhi oleh pihak Britain kerana beliau tidak terhutang budi dengan Britain secara langsung seperti Tunku dan Tun Razak. ${ }^{27}$

Dibandingkan dengan Tunku, pihak Britain bukan sahaja memberi bantuan dalam bidang ekonomi tetapi mereka juga menjaga kepentingan politik Parti Perikatan dengan menyalurkan bantuan kewangan kepada Parti Perikatan terutama pada waktu menghadapi pilihan raya. Tujuan pihak Britain menyebelahi Parti Perikatan adalah bagi membantu supaya Parti Perikatan kekal memerintah Malaya. Ini dapat dirujuk pada tahun 1959, di mana firmafirma Britain telah membantu dana Parti Perikatan dalam pilihan raya pada tahun tersebut dengan alasan kerajaan di bawah Parti Perikatan memberi layanan istimewa kepada mereka. Menurut sumber jumlah yang dikutip tidak diketahui jumlahnya. Amalan memberi sumbangan politik membantu Parti Perikatan adalah besar dan tersebar luas dalam firma Britain. $^{28}$

Berbeza dengan era pentadbiran Dr. Mahathir yang tidak mendapat layanan yang baik dari pihak Britain sehingga beliau telah mengambil tindakan yang agak serius dengan mengisytiharkan BBL. Ianya bukanlah satu tindakan yang dirancang secara rapi oleh Dr. Mahathir tetapi tindakan tersebut telah berjaya membuka mata pihak Britain yang selama ini mengambil jalan mudah dalam menyelesaikan beberapa masalah dan turut memberi tekanan 
kepada Malaysia terhadap apa yang Malaysia rasa tidak berpuas hati dalam hubungan keduadua negara. ${ }^{29}$

Karminder Singh pula melihat BBL dengan menyatakan ianya dilaksanakan kerana mahu menamatkan perniagaan antara kaum Cina dengan pihak Britain. Ini bagi memberi peluang kepada pihak bumiputera berurus niaga dengan pihak Britain. ${ }^{30}$ Pihak Britain telah menilai Dr. Mahathir dengan menyatakan bahawa: "He was a Malay chauvinist by temperament who disliked the local Chinese community's disproportionate position of resented the recent decision of certain local British firms (eg. Dunlop Estates and Guthrie) sell out to Malaysian Chinese rather than Malay interests." ${ }^{31}$ Ini merupakan soal DEB yang dipertahankan oleh Mahathir supaya pihak Britain dengan sewenang-wenangnya tidak mempermainkan perlaksanaan DEB yang mahu dilaksanakan sejak Tun Razak lagi. ${ }^{32}$ Kemarahan Malaysia terhadap firma-firma Britain yang tidak mahu turut sama dalam perlaksanaan DEB sampai kemuncaknya apabila Mahathir mengambil tindakan yang lebih tegas dan serius iaitu perlaksanaan BBL.

Persoalan ekonomi kaum Melayu yang jauh ketinggalan daripada kaum Cina tidak dapat disamakan lagi dan ditambah pula campurtangan pihak Britain yang menghalang usaha Malaysia untuk merapatkan jurang ekonomi yang besar sejak zaman Tun Razak lagi walaupun ada usaha-usaha untuk mengurangkan jurang ekonomi antara kaum Melayu dengan kaum Cina. ${ }^{33}$

Selain itu, imbangan perdagangan di antara kedua-dua negara lebih menguntungkan pihak Britain. Sejak zaman Tun Razak lagi, Malaysia telah mengalami imbangan pembayaran yang berat sebelah kepada pihak Britain. Ini berlarutan sehingga era Dr. Mahathir yang kemudiannya telah menyuarakan rasa tidak puas hati terhadap soal imbangan pembayaran antara kedua-dua negara. Soal imbangan pembayaran yang berat sebelah sekian lama antara Malaysia dengan Britain juga menjadi faktor Dr. Mahathir bertindak dengan begitu berani mengisytiharkan BBL. Ini dapat dirujuk apabila melihat jumlah perdagangan di antara Malaysia dan United Kingdom pada tahun 1975 yang mencatitkan jumlah dagangan sebanyak RM1,406.12 juta dan pada tahun 1980 berjumlah RM2,053.1 juta. Walaupun jumlah dagangan pada tahun 1980 menampakkan peningkatan tetapi pada tahun 1978 perdagangan dengan United Kingdom berjumlah enam peratus daripada jumlah keseluruhan perdagangan dan jatuh kepada lima peratus dan seterusnya pada tahun 1980 ditahap hanya empat peratus sahaja. Walau bagaimanapun pihak Britain masih kekal menjadi penyumbang terbesar perdagangan dalam EEC. ${ }^{34}$ Corak perdagangan Britain terhadap Malaysia telah menurun.

Melihat kepada imbangan pembayaran pada tahun 1976 Malaysia mengalami defisit dagangan sebanyak RM57.4 juta dan bertambah pada tahun 1977 sebanyak RM77.1 juta dan pada tahun 1980 bertambah lagi sebanyak RM475.1 juta.Pada tahun 1980, jumlah import sebanyak RM1,274.1 juta dan jumlah eksport sebanyak RM779.0 juta. ${ }^{35}$ Manakala pada tahun 1981, jumlah import sebanyak RM2,214 juta dan jumlah eksport sebanyak RM804 juta. ${ }^{36}$ Dibandingkan di antara dua tahun iaitu tahun 1980 dan 1981 turut menunjukkan corak jumlah perdagangan yang menurun. Malaysia terus mengalami defisit dagangan dengan Britain.

Ketidak seimbangan perdagangan ini telah mendapat perhatian Dr. Mahathir dan menyuarakan rasa tidak puas hati terhadap kedudukan imbangan perdagangan di antara Malaysia dan Britain. Di dalam tahun 1983, kedudukan Britain di tempat ke lapan sebagai rakan perdagangan dengan 3.1 peratus daripada perdagangan keseluruhan Malaysia. Malaysia mengeksport ke Britain sebanyak 2.7 peratus manakala import Malaysia daripada Britain sebanyak 3.5 peratus. $^{37}$ Kedudukan perdagangan antara Malaysia dan Britain lebih menguntungkan pihak Britain. Kedudukan tidak seimbang ini telah dinyatakan oleh Dr. Mahathir: "There is obviously a need to redress this imbalance.",38 
Jadual 1.0 Impot/Ekspot Malaysia-Britain 1980-1990 RM juta

\begin{tabular}{|l|c|c|c|c|c|c|c|c|c|c|c|}
\hline Tahun & $\mathbf{1 9 8 0}$ & $\mathbf{1 9 8 1}$ & $\mathbf{1 9 8 2}$ & $\mathbf{1 9 8 3}$ & $\mathbf{1 9 8 4}$ & $\mathbf{1 9 8 5}$ & $\mathbf{1 9 8 6}$ & $\mathbf{1 9 8 7}$ & $\mathbf{1 9 8 8}$ & $\mathbf{1 9 8 9}$ & $\mathbf{1 9 9 0}$ \\
\hline Ekspot & 779 & 804 & 772 & 895 & 988 & 986 & 1155 & 1432 & 1933 & 2540 & 3137 \\
\hline Impot & 1271 & 1214 & 1185 & 1088 & 1186 & 1108 & 1087 & 1359 & 2136 & 3280 & 4327 \\
\hline Imbangan & -492 & -410 & -413 & -193 & -198 & -122 & 68 & 73 & -203 & -740 & -1190 \\
\hline
\end{tabular}

Sumber: i) Angka-angka anggaran bagi perdagangan luar bagi tempoh Januari hingga Disember 1983, Jabatan Perangkaan Malaysia

ii) Angka-angka anggaran bagi perdagangan luar bagi tempoh Januari hingga Disember 1985, Jabatan Perangkaan Malaysia

iii) Angka-angka anggaran bagi perdagangan luar bagi tempoh Januari hingga Disember 1986, Jabatan Perangkaan Malaysia

iv) Buku TahunanPerangkaan Malaysia 1990, Kuala Lumpur: Jabatan Perangkaan Malaysia, Julai 1991

\section{Carta 1.0 Impot/Ekspot Malaysia-Britain 1980-1990 RM juta}

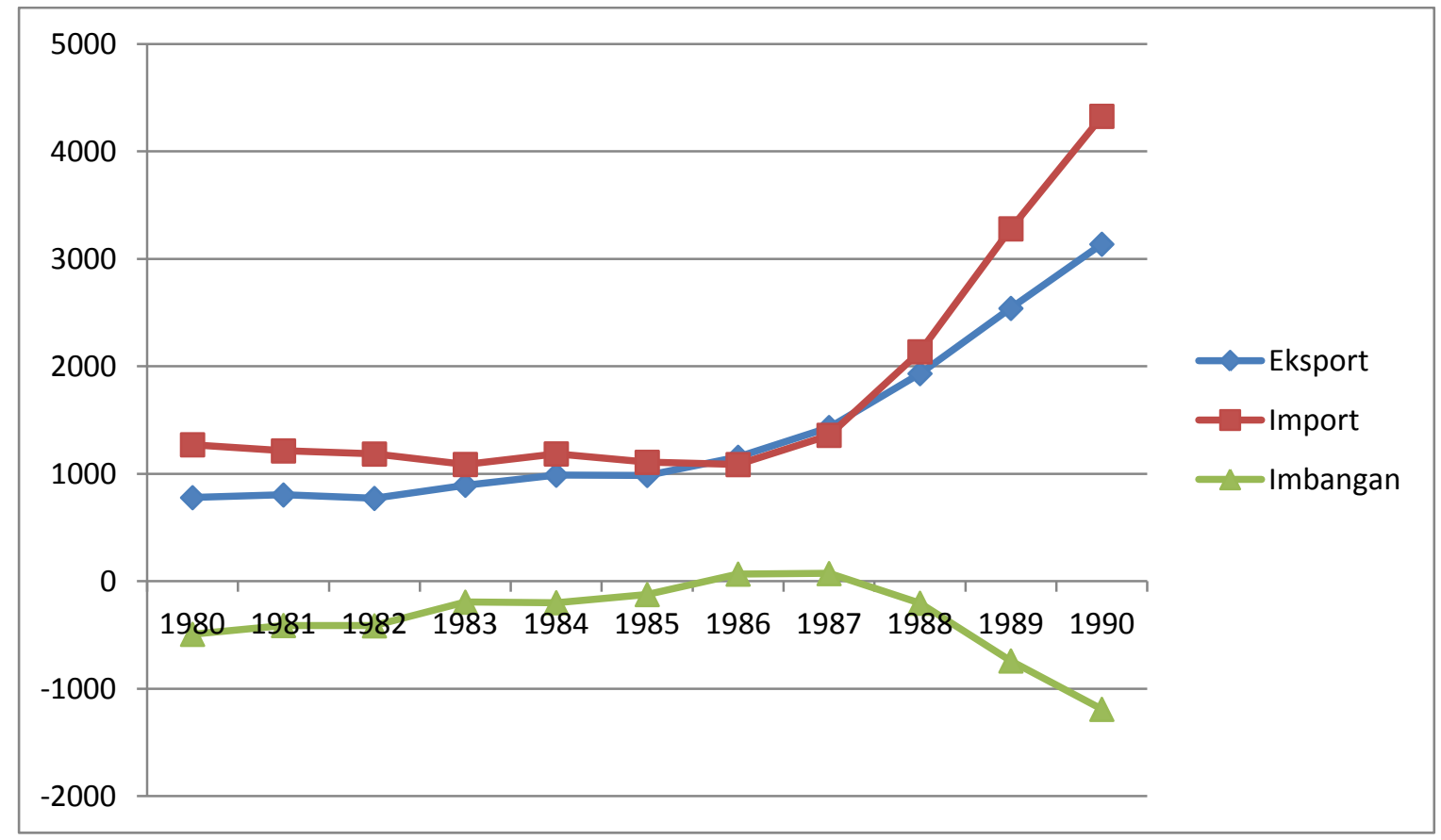

Menurut sumber di atas pada tahun 1980 sehingga 1985, Malaysia telah mengalami defisit imbangan perdagangan dengan Britain kecuali pada tahun 1986 dan 1987 iaitu surplus sebanyak RM68 juta dan RM73 juta. Kemudian kembali mengalami defisit pada tahun 1988 sehingga tahun 1990. Walau bagaimanapun, bermula tahun 1986 sehingga 1990 menampakkan ada peningkatan perdagangan antara kedua-dua negara dan Malaysia masih mengalami defisit dalam imbangan perdagangan.

\section{Proses perlaksanaan BBL}

Tindakan Dr. Mahathir dianggap tergesa-gesa tanpa dibincangkan dalam mesyuarat kabinet terlebih dahulu dan bertindak secara sendirian. Walau bagaimanapun, beliau mempunyai 
strategi sendiri dan tindakan beliau adalah melalui satu proses kejutan terhadap Britain. Dr. Mahathir telah memberi arahan kepada Ketua-ketua Setiausaha Kementerian melalui Ketua Setiausaha Negara, Dato' Alwi Jantan, Surat Pekeliling Am Sulit Bil. 4 Tahun 1981 bertarikh 28 September 1981 supaya semua perakuan kontrak bekalan, perkhidmatan perundingan dan lain-lain urusniaga dengan firma-firma Britain atau firma-firma usahasama dengan Britain perlu dirujuk kepada Unit Penyelarasan dan Pelaksanaan (UPP), Jabatan Perdana Menteri, terlebih dahulu sebelum diluluskan. ${ }^{39}$ Kenyataan Dr. Mahathir: "All Government departments and agencies will have to get the Prime Minister's Department's endorsement before they can award any tender to a British concern." ${ }^{40}$ Tiap-tiap perakuan Lembaga Tender ini hendaklah juga menyatakan pilihan kedua dari firma bukan Britain atau firma bukan usahasama dengan Britain sebelum merujuk kepada Jabatan Perdana Menteri. ${ }^{41}$ Ia bukanlah satu tindakan mengharamkan firma-firma Britain daripada melibatkan tender dengan Malaysia. Arahan yang dikeluarkan adalah tidak membenarkan kontrak daripada Britain sahaja tetapi perlu adanya kontrak dari negara lain sebagai pilihan lain. ${ }^{42}$

Apabila BBL diisytiharkan pada 2 Oktober, $1981,{ }^{43}$ pihak Britain tidak mahu mengambil sebarang tindak balas terhadap apa yang dilakukan oleh Malaysia kerana tidak mahu keadaan menjadi bertambah keruh. Setiausaha Kedua Suruhanjaya Tinggi di Malaysia, S.M. Scaddan menyatakan pihak Britain hanya tunggu dan lihat kesan daripada polisi baru kerajaan Malaysia terhadap tender-tender yang dikeluarkan kepada syarikat-syarikat Britain. "We do not want to get too uptight...we will take it calmly and see how it affects British companies." 44

Di dalam melaksanakan BBL, Ketua Pengarah Unit Penyelarasan dan Perlaksanaan, Jabatan Perdana Menteri, telah memberi tiga prinsip digunakan untuk membuat pilihan iaitu: pertama, sekiranya ada alternatif tawaran selain daripada firma Britain maka tawaran dari firma bukan daripada Britain adalah dipilih. ${ }^{45}$ Dr. Mahathir menyatakan: "ministries, departments and agencies would have to submit to his department any award to be made to a British firm together with a non-British alternative choice The procedure also applies to British joint-venture companies including those with Malaysian interests." ${ }^{46}$ Sebagai contoh pembelian traktor bagi Syarikat Gula Padang Terap. Walaupun terdapat model British dan murah lebih kurang 20 peratus namun model dari Jepun dipilih. ${ }^{47}$ Kedua, bagi pelabur Britain yang telah melabur dan mengeluarkan barang-barang atau khidmat dalam negara ini tidak kira sama ada syarikat-syarikat itu merupakan syarikat usahasama Britain dengan orang tempatan atau syarikat-syarikat dimiliki seratus peratus pihak Britain. ${ }^{48}$ Ketiga, arahan ini meliputi bukan sahaja kerja-kerja khidmat dan barang-barang buatan Britain, tetapi juga orang perseorangan Britain. Satu contoh dalam kes ini ialah berkaitan dengan permohonan dari Kementerian Pengangkutan untuk menggunakan khidmat "Crown Agent" bagi mengambil pegawai-pegawai untuk Jabatan Laut. Perdana Menteri menolak permohonan ini dan sebaliknya mengesyorkan supaya pegawai-pegawai itu diambil dari negara Asia seperti Indonesia, Pakistan, India dan Bangladesh. Di satu kes yang lain pula di mana Kementerian Kewangan telah memohon untuk melantik kumpulan konsultan Britain bagi mengkaji insuran, Perdana Menteri telah membenarkannya kerana beberapa sebab sejarah, sistem insuran di Malaysia telah terikat dengan sistem yang diamalkan oleh Britain. ${ }^{49}$

Dalam usaha melaksanakan BBL, Ketua Setiausaha Kementerian Luar Negeri telah melihat terdapatnya perbezaan objektif yang mahu dicapai dengan memberi dua senario sidang akhbar iaitu sidang akhbar semasa Mesyuarat ASEAN-EEC di London (13-15 Oktober 1981) Menteri Luar Negeri telah membuat kenyataan bahawa hubungan kerajaan dan rakyat Malaysia masih merasakan hubungan mesra dengan Britain tetapi perasaan ini tidak dibalas dengan sebaiknya malah seringkali diperkecilkan dan diketepikan untuk faedah dan keuntungan negara-negara sekutunya. Malaysia perlu menilai semula hubungan yang dilalui bersama dan kebetulan pula ianya berlaku dalam tempoh kepimpinan Dr. Mahathir. Ini 
bertujuan untuk memberitahu pihak Britain bahawa firma-firma dari Britain perlu bersaing antara satu sama lain dengan firma-firma dari negara lain. Malaysia masih meneruskan hubungan istimewa dengan Malaysia tetapi hanya dengan status yang sama rata. ${ }^{50}$

Perlaksanaan BBL adalah satu tindakan Malaysia yang mendahului kontrak negara lain terlebih dahulu walaupun kontrak daripada pihak Britain adalah lebih rendah dan langkah ini dikecualikan bagi barangan pembuatan daripada Britain. ${ }^{51}$ Menurut akhbar The Glasgow Herald menyatakan arahan Dr. Mahathir adalah lebih keras daripada Menteri Luar Negeri Malaysia. ${ }^{52}$ Ghazali Shafie memberi penjelasan bahawa tindakan BBL lebih menjuruskan kepada firma-firma Britain dan bukan kepada kerajaan Britain. Walau bagaimanapun arahan ini tidak dihiraukan oleh firma-firma Britain. Ini telah menambahkan lagi ketegangan hubungan Malaysia dengan Britain. Ghazali Shafie menegur sikap firma-firma yang tidak memberi perhatian serius terhadap arahan BBL: "this was "not a helpful attitude" as the businessman should instead be asking "please tell us where we're wrong." 53

Manakala satu sidang khas akhbar bersama Dr. Mahathir pada 26 Oktober 1981 telah menjelaskan Malaysia tidak bercadang memutuskan hubungan perdagangan dengan Britain atau mengenakan boikot ke atas barangan Britain. Kerajaan Malaysia turut mengalu-alukan syarikat-syarikat Britain yang ingin melabur di Malaysia. Dr. Mahathir menegaskan: "Malaysia is not cutting off trade relations with Britain nor carrying out a general boycott of British goods." 54

Malaysia akan melaksanakan satu tindakan untuk tidak membeli barangan Britain atau memilih khidmat daripada Britain sekiranya ada alternatif lain yang membolehkan Malaysia membuat pilihan. Jika tidak ada pilihan lain barulah barangan atau perkhidmatan Britain dipilih. ${ }^{55}$ Dr. Mahathir menjelaskan: "All we are saying is that we will not buy British if we can help it. But we will buy if we cannot help it." 56

Susulan daripada arahan Dr. Mahathir telah diadakan satu mesyuarat Ketua-ketua Setiausaha Kementerian pada 31 Oktober 1981 yang telah membincangkan isu Bekalan dan Kontrak Firma-Firma British dan juga beberapa isu yang dibangkitkan terutama implikasi serta kesan daripada arahan ini ke atas projek pembangunan yang telah terikat perjanjian dengan firma-firma Britain sebelum dari arahan ini dikeluarkan, orang perseorangan Britain yang berkerja di sektor-sektor mahir seperti MAS, MISC dan guru-guru khas Bahasa di Maktab-maktab perguruan dan juga di universiti-universiti. ${ }^{57}$

Di dalam mesyuarat khas pada 9 November 1981 telah memutuskan arahan Dr. Mahathir adalah merupakan satu dasar kerajaan dan telah berkuatkuasa mulai tarikh Surat Pekeliling Am Sulit Bil. 4 Tahun 1981 bertarikh 28 September 1981. ${ }^{58}$

Mahathir tidaklah bertindak secara melulu tetapi mempunyai strategi dalam melaksanakan BBL dengan mengarah Ketua Setiausaha Negara untuk melaksanakan BBL, berbincang, memantau perlaksanaan BBL serta melihat perkembangan yang berlaku.

\section{Reaksi Diplomatik}

Selepas diumumkan polisi BBL, ia mendapat respon yang menggalakkan dan menjadi tajuk perbincangan utama bagi Menteri-Menteri Britain yang datang melawat Malaysia. Begitu juga dengan Suruhanjaya Tinggi Britain di Kuala Lumpur turut membincangkannya dengan pihak Wisma Putra di Kuala Lumpur. ${ }^{59}$

Pada 5 Oktober 1981, perjumpaan telah diadakan oleh John Nott (Setiausaha Pertahanan Britain) dengan Dr. Mahathir. John Nott menyatakan bahawa tindakan kerajaan Malaysia itu adalah sebagai beza membezakan (diskriminasi) terhadap firma-firma Britain. Dr. Mahathir menegaskan tindakan tersebut adalah disebabkan tindakan yang telah dilakukan oleh pihak Britain dan sikap pihak Britain terhadap Malaysia. Hubungan ini boleh dipulihkan sekiranya pihak Britain mengambil langkah untuk membetulkannya. ${ }^{6}$ 
Pada 15 Oktober 1981, satu sidang akhbar telah diadakan di London oleh Menteri Luar Negeri dan menjelaskan tindakan kerajaan Malaysia bukanlah ditujukan kepada Kerajaan Britain tetapi kepada firma-firma Britain sahaja. ${ }^{61}$

Pada 10 November 1981, Pesuruhjaya telah bertemu dengan Ketua Setiausaha Wisma Putra. Pesuruhjaya Tinggi Britain meminta kebenaran untuk bertemu Timbalan Perdana Menteri dan menyatakan bahawa kerajaan Britain menyedari akan kemahuan pihak kerajaan Malaysia yang menitik beratkan dan bersungguh-sungguh untuk melaksanakan Dasar Ekonomi Baru. Kerajaan Malaysia tidak ingin melihat firma-firma Britain menjadi penghalang dengan bertindak secara songsang terhadap Dasar Ekonomi Baru. Pesuruhjaya Tinggi Britain telah memberi ingatan terhadap firma-firma Britain bahawa mereka perlu memahami sepenuhnya Dasar Ekonomi Baru yang dilaksanakan oleh kerajaan Malaysia. Mereka juga perlu merujuk kepada Suruhanjaya Tinggi bagi membincang terlebih dahulu dengan Suruhanjaya Tinggi sebelum mengambil apa-apa langkah yang mungkin menyentuh Dasar Ekonomi Baru, dan sekiranya sebarang firma Britain mahu memindah milik sahamsaham mereka perlulah memberi peluang kepada firma-firma Bumiputra membuat pilihan utama untuk menolak (right of first refusal). ${ }^{62}$

Tindakan BBL adalah manifestasi Dr. Mahathir yang merasa tidak puas hati dengan tindakan pihak Britain yang dianggap telah mensabotaj aspirasi orang Melayu melalui Dasar Ekonomi Baru. Tindakan Britain ini dianggap sebagai mengeksploitasi ekonomi dan layanan yang tidak adil yang ditberikan kepada orang Melayu dari pihak Britain. Pihak Britian perlu diambil tindakan bagi mengubah situasi ini supaya ia tidak berlarutan. ${ }^{63}$

Pada 3 Februari 1982, Pesuruhjaya Tinggi Britain melawat Menteri Luar Negeri dan memberitahu bahawa beliau telah berbincang dengan pihak firma-firma Britain yang turut mengambil berat tentang masalah yang ada dan mereka yang mempunyai kontrak-kontrak di Malaysia. Tujuan mereka ialah untuk memberi penjelasan atas Dasar Ekonomi Baru dan juga untuk mencari jalan penyelesaian masalah-masalah yang berkaitan. ${ }^{64}$

Dalam perjumpaan ini, Menteri Luar Negeri menegaskan masalah yang dihadapi bukanlah masalah diplomatik tetapi jika tidak diselesaikan dengan segera akan mengakibatkan ketegangan hubungan di antara kedua-dua negara. Menteri Luar Negeri memberi ingatan bahawa langkah-langkah pemulihan yang disenaraikan tidak akan bermakna sekiranya pihak Britain tidak mengubah sikap terutama ahli-ahli perniagaan Britain. ${ }^{65}$

Seterusnya lawatan ke Kuala Lumpur oleh Lord Carrington (Setiausaha Hal Ehwal Luar Britain) pada 6 Februari hingga 8 Februari $1982 .{ }^{66}$ Dalam rangka lawatan ke Malaysia, beliau telah bertemu dengan Dr. Mahathir dan menyatakan bahawa kerajaan Britain memahami sepenuhnya dan bersimpati dengan usaha-usaha kerajaan Malaysia untuk melaksanakan Dasar Ekonomi Baru. Pihak Britain telah membuat perubahan dan berjanji akan berusaha supaya pihak Britain lebih memahami dan sedar. ${ }^{67}$

Dalam pertemuan ini masalah kenaikan yuran pelajar Malaysia di Britain turut dibincangkan. Kerajaan Britain mencadangkan peruntukkan kewangan yang boleh diberikan kepada pelajar-pelajar Malaysia yang belajar di Britain sebagai biasiswa. Begitu juga dengan peniaga-peniaga Britain yang mahu turut membantu dengan menyertai skim bantuan menerusi Overseas Students Trust. ${ }^{68}$

Selain itu, Britain turut mencadangkan penubuhan satu Jawatankuasa Bersama antara Kerajaan Malaysia dan Britain yang dikemukakan oleh Lord Carrington. Dr. Mahathir tidak memberi sebarang komen dan menyatakan kesediaannya untuk memberi pertimbangan dahulu. ${ }^{69}$

Dalam usaha untuk memulihkan hubungan yang sedia ada, kerajaan Britain telah menawarkan pinjaman sebanyak 220 juta sebagai 'soft loan' tanpa faedah dan sebanyak $£ 57$ juta sebagai 'commercial credit' yang dikenakan kadar faedah sebanyak 73/4 berkuatkuasa dari Januari 1981 hingga 1984. Walau bagaimanapun, pinjaman ini tertakluk kepada 
pembelian alat-alat kelengkapan perkidmatan dan barang-barang dari Britain. Pihak kerajaan Malaysia telah mengesan beberapa projek bagi mendapat pinjaman daripada kerajaan Britain. $^{70}$ Tindakan ini tidak dianggap sebagai satu cara tindak balas pihak Britain bagi menangani polisi BBL. Namun begitu, pinjaman tersebut memerlukan pihak Malaysia membeli barangan dan perkhidmatan dari Britain. ${ }^{71}$ Secara tidak langsung ia membantu pihak Britain untuk menjual barangan dan perkhidmatan kepada pihak Malaysia walaupun ada usaha dari kerajaan Malaysia untuk tidak membeli barangan dan perkhidmatan dari Britain.

Pihak Britain juga turut menambahkan bantuan teknik bagi tahun 1982/83 kepada Unit Perancang Ekonomi sebanyak $£ 800,000.00$ daripada Pesuruhjaya Tinggi British di Kuala Lumpur. Ianya ditafsirkan sebagai satu kesan yang positif kerana sebelum ini tawaran bantuan teknik ini hanya $£ 500,000.00$. Kerajaan Britain bermurah hati untuk menambah bantuan sebanyak $£ 300,000.00 .^{72}$ Walau bagaimanapun, tindakan ini menyebabkan kerajaan Malaysia masih bergantung kepada kerajaan Britain. Walau bagaimanapun, usaha-usaha ini gagal untuk mengubah pendirian Dr. Mahathir untuk menarik semula BBL.

Akhirnya satu pertemuan tidak rasmi telah dilakukan di antara Margaret Thatcher dengan Dr. Mahathir di London pada bulan Mac, 1983. ${ }^{73}$ Pertemuan ini membuktikan bahawa pihak Britain menerima kedudukan Malaysia sebagai sebuah negara yang merdeka dan pandangan serta rasa tidak puas hati Malaysia perlu diberi perhatian. Sekembalinya Dr. Mahathir daripada lawatan tidak rasmi beliau ke London dan selepas pertemuan beliau dengan Thatcher, Dr. Mahathir mengambil keputusan untuk menarik balik tindakan BBL. ${ }^{74}$ Mahathir berkata: "The Prime Minister's Department will no longer vet any contract or tender awards involving British firms in any project for Government agencies and departments." 75

Akhirnya ketegangan hubungan luar antara Malaysia dan Britain berakhir dan arahan dikeluarkan melalui surat bertarikh 31 Mac 1983. Semua perakuan kontrak bekalan, perkhidmatan, perundingan dan lain-lain urusniaga dengan firma Britain atau firma usahasama dengan Britain tidak perlu lagi dirujukkan kepada Unit Penyelarasan Perlaksanaan, Jabatan Perdana Menteri tetapi kepada Lembaga Tender. ${ }^{76}$ BBL hanya bertahan selama lapan belas bulan dengan perubahan sikap Britain yang agak positif telah menjalinkan semula hubungan Malaysia dengan Britain. ${ }^{77}$ Dr. Mahathir turut menyatakan bahawa turunnya nilai pound telah menyebabkan harga barangan Britain telah menjadi murah. $^{78}$

BBL telah ditamatkan sebelum kedatangan Margaret Thatcher ke Malaysia pada tahun 1985. Walau bagaimanapun ini tidak bermakna pihak Malaysia akan membeli barangan Britain dahulu tetapi barangan Britain akan bertanding sama rata dengan barangan lain dan tidak akan ada diskriminasi. Dr. Mahathir menegaskan: "So, may I repeat, Buy British Last Policy is dead and has been buried for good."

Walaupun polisi BBL telah ditamatkan dan sempena lawatan Dr. Mahathir ke London namun ada pihak tertentu yang sengaja menakutkan pelabur-pelabur Britain supaya tidak melabur di Malaysia. Ada yang menuduh Malaysia mengamalkan dasar memilikkan negara serta Malaysia akan menukar syarat-syarat baru bagi pelabur-pelabur asing selepas setiap lima tahun. ${ }^{80}$

Tindakan Mahathir ini telah memberi reaksi positif daripada pihak Britain untuk mengambil inisiatif pemulihan hubungan dengan Malaysia. Pihak Britain telah menghantar wakil bagi mencari punca kepada keretakan hubungan dengan Malaysia dan mencari jalan penyelesaian daripada kemelut BBL. Akhirnya membawa pertemuan kedua pemimpin negara bagi mencari jalan penyelesaian dan merapatkan semula hubungan kedua-dua negara. 


\section{Kesan pelaksanaan BBL}

Kesan daripada tindakan BBL telah mendapat liputan luas dalam akhbar-akhbar tempatan serta akhbar-akhbar luar negara terutama sekali di United Kingdom yang telah membuat tafsiran bahawa kerajaan Malaysia telah mengamalkan prinsip diskriminasi ke atas firmafirma Britain. Manakala dalam keluaran editiorial Financial Times pada 1 Oktober 1981 telah menuduh Malaysia memboikot firma-firma dan barang-barang Britain. ${ }^{81}$ Pihak media terutama di Britain mengambil kesempatan untuk mengecam dan mengkritik tindakan BBL tanpa memahami kenapa isu ini ditimbulkan dan tindakan yang dikenakan. Ghazali Shafie menjelaskan: "Then the newspapers came in and said there was a boycott of British goods." Tambah beliau lagi: "We have never said a word about boycott." ${ }^{\circ 3}$ Begitu juga firma-firma Britain yang beroperasi di Malaysia sangat marah terhadap kerajaan Britain dan wartawan dengan tindakan mereka yang tidak memahami apa yang sebenar berlaku di Malaysia. ${ }^{84}$

Kenyataan ini dari pandangan dan penerimaan akhbar-akhbar di Britain telah membawa makna bahawa kerajaan Malaysia telah mewujudkan diskriminasi barangan dan perkhidmatan daripadaBritain. ${ }^{85}$ Tindakan ini bukanlah untuk mendiskriminasikan barangan dan perkhidmatan Britain tetapi memberi peluang kepada negara lain untuk bersaing dengan Britain.

Tindakan Malaysia yang membezakan negara-negara Eropah lain bagi kepentingannya telah menyebabkan Britain tidak berpuashati. Namun begitu Malaysia telah menarik semula perbezaan yang dikenakan supaya firma-firma Britain dapat bersaing semula dengan firmafirma dari negara lain secara saksama."...to make sure that everybody else have the same highest level of standard that we required." dianggap istimewa dengan Britain tetapi berasaskan status yang setaraf dan sama rata di antara kedua-dua negara. ${ }^{87}$

Perbincangan telah diadakan dalam satu mesyuarat dan telah merumuskan tidak dapat ditentukan dengan tepat sama ada dasar Kerajaan mengenai firma-firma Britain ini boleh ditakrifkan sebagai satu amalan diskriminasi sebagaimana yang dianggap oleh akhbar-akhbar Britain serta juga Attache Perdagangan Britain di Malaysia. ${ }^{88}$ Dari pihak Malaysia adalah lebih tepat dan wajar dasar ini diterangkan sebagai penarikan balik keutamaan layanan kepada Britain (removal of bias preference for the British) dan untuk menegakkan pendirian Malaysia sebagai sebuah negara yang berdaulat, bebas dan berkecuali dalam kumpulan negara-negara di dunia ini. ${ }^{89}$ Ini adalah sebagai notis kepada Britain bahawa mereka bukan lagi dianggap istimewa. Walaupun Malaysia pernah dijajah oleh Britain, tidak bermakna Malaysia perlu tunduk kepada Britain. Malaysia tidak mahu menilai tender Britain mengikut merit daripada "past sentimentality". 90

Perlaksanaan BBL kepada pihak syarikat-syarikat Britain telah menyebabkan mereka mengalami kerugian sebanyak $£ 15.5$ juta dalam tempoh beberapa bulan pertama dilaksanakan BBL. Anthony Kershaw, British House of Common Foreign Affairs Select Committee Chairman, menganggarkan kerugian antara $£ 20$ juta hingga $£ 50$ juta. ${ }^{91}$ Begitu juga dengan eksport ke Malaysia telah jatuh daripada RM1,215 juta pada tahun 1981 kepada RM1,117 juta pada tahun $1984 .^{92}$

Secara tidak langsung, Malaysia telah melonggar sedikit syarat-syarat Dasar Ekonomi Baru bagi menarik lebih ramai pelabur asing. Pada 30 September 1986, Dr. Mahathir telah menyatakan pelaburan baru bermula Oktober 1986 sehingga Disember 1990, syarikat asing dibenarkan memiliki seratus peratus syarikat di Malaysia ${ }^{93}$ sekiranya eksport lima puluh peratus atau lebih produk-produk Malaysia atau ke zon perdagangan bebas Malaysia. Syarat pengambilan pekerja Malaysia oleh syarikat asing yang mengambil seramai 350 orang atau lebih akan diberi kuasa untuk mendapat sebanyak mana ekuiti yang mereka mahukan. Walau bagaimanapun sekiranya ekuiti syarikat asing kurang daripada seratus peratus, maka ia akan tertakluk kepada Dasar Ekonomi Baru iaitu memerlukan penyertaan orang Melayu sebanyak 
tiga puluh peratus. ${ }^{94}$ Tolak ansur perlu dilakukan bagi menarik lebih ramai pelabur asing untuk melabur di Malaysia. ${ }^{95}$

Terdapatnya usaha-usaha untuk memulihkan hubungan antara Malaysia dan Britain yang dilakukan oleh ahli perniagaan kedua-dua negara dengan menubuhkan ruang kepada keduadua ahli perniagaan untuk berinteraksi dan dapat memahami antara satu sama lain. Dr. Mahathir berharap persatuan ini dapat memainkan peranan yang lebih berkesan bagi mengatasi masalah-masalah yang akan dihadapi nanti. ${ }^{96}$

Ada yang berpendapat perlaksanaan BBL telah merugikan Malaysia. Menurut Dr. Mahathir semasa dasar BBL dilaksanakan, negara tidak mengalami apa-apa kerugian oleh kerana pembelian masih dibuat berasaskan kepada persaingan tawaran (competitive bidding) dan pemilihan dibuat bagi tawaran yang paling menguntungkan. ${ }^{97}$

Secara amnya, barang-barang buatan British telah menjadi lebih kompetitif kerana kejatuhan nilai pound. ${ }^{98}$ Terdapat barang-barang buatan negeri lain sebagai alternatif kepada barang-barang British kecuali alat-alat ganti yang jentera asalnya dibeli dari Britain dan juga alat-alat yang mempunyai 'patent right'. Juga terdapat agensi-agensi kerajaan yang memilih untuk membeli barang-barang British disebabkan oleh hubungan perdagangan yang sedia ujud di antara kedua pihak dan memberi alasan yang menyatakan barang-barang bukan British tidak menepati spesifikasi. ${ }^{99}$

Tindakan Dr. Mahathir menguatkuasakan BBL bukanlah sebagai keputusan muktamat dalam menamatkan hubungan istimewa dengan Britain. Ia adalah satu tamparan sebagai tanda amaran supaya pihak Britain tidak mengambil mudah terhadap Malaysia lagi. ${ }^{100}$ Melihat kepada sejarah perhubungan Malaysia dengan Britain adalah memberi kelebihan kepada pihak Britain. Oleh sebab itu, Britain tidak memberi perhatian secara serius terhadap rungutan dan rasa tidak puas hati Malaysia. Walaupun ramai yang beranggapan beliau adalah seorang anti Barat namun beliau adalah seorang yang pragmatik dan tidak terlalu beremosi. Tindakan BBL adalah untuk membuktikan kepada pihak Britain bahawa Malaysia tidak lagi terlalu bergantung kepada Britain dan pada bila-bila masa boleh mengenepikan Britain terutama dalam soal ekonomi. Malaysia boleh bertindak secara rasional dan praktikal. Dr. Mahathir berkata:

"Malaysia has always welcomed foreign investors. We may impose conditions in order that we share in the benefits but we have never been anti-foreign. We have never indulged in nationalization. Even we were saying "Buy British Last" we still laid out the welcome mat for British investors."101

Dr. Mahathir menjelaskan kedudukan Malaysia sebagai negara kecil tetapi perlu dilayan sama rata dalam ucapan di London pada 23hb Julai 1987 sempena makan tengahari dikendalikan oleh Konfendrasi Industri Britain. ${ }^{102}$ Britain pernah menjadi pelabur terbesar di Malaysia, hubungan Malaysia dengan Britain adalah hubungan yang mempunyai sejarah tersendiri dan tidak dinafikan banyak kebaikan yang telah dilakukan sebagai tuan penjajah. Dalam ucapan tersebut Dr. Mahathir terus menyatakan bahawa kekurangan pelaburan Britain di Malaysia walaupun terdapat banyak peluang untuk melabur di Malaysia. Ini adalah kerana sikap memandang Britain terlalu tinggi. Walau bagaimanapun, Dr. Mahathir menegaskan: "Malaysia, of course, is not in the same league as Britain, but young nations do tend to take equality seriously.","103

Selepas BBL ditamatkan terdapat tanda-tanda positif terhadap hubungan dagangan Malaysia dengan Britain. Menjelang akhir 1984, jumlah modal pelaburan Britain dalam bidang pengeluaran berjumlah RM765 juta iaitu ketiga terbesar selepas Singapura sebanyak RM1.42 juta dan Jepun sebanyak RM1.12 juta. ${ }^{104}$ Dalam lapan bulan pertama pada tahun 
1986 berbanding tempoh yang sama pada tahun 1985, pelaburan Britain yang telah diluluskan meningkat 216 peratus daripada RM5.2 juta kepada RM18.7 juta. ${ }^{105}$

Britain merupakan salah sebuah pelabur terbesar di Malaysia hanya mempunyai sebelas projek sahaja dengan pelaburan berjumlah $\$ 863.8$ juta yang diluluskan pada tahun 1990 berbanding dengan Taiwan yang memperolehi 235 projek yang diluluskan dan Jepun pula hanya 112 projek yang diluluskan. Taiwan dan Jepun mempunyai jumlah pelaburan sebanyak $\$ 9,500$ juta. Prestasi ini menunjukkan Britain tidak memberi sumbangan yang besar dalam peningkatan pelaburan luar di Malaysia. ${ }^{106}$

Dari sudut hubungan perdagangan dua hala bagi tempoh empat bulan pertama 1990 terdapat peningkatan tiga puluh satu peratus. Statistik yang dikeluarkan oleh Suruhanjaya Perdagangan Malaysia di London menunjukkan nilai jumlah perdagangan dua hala sehingga bulan April 1990 adalah $£ 434$ juta (RM2.17 bilion) dengan Malaysia memperolehi lebihan sebanyak $£ 60$ juta (RM300 juta). Dibandingkan pada tahun lepas (1989) memperolehi kirakira RM5.59 bilion dengan lebihan sebanyak RM1.17billion. ${ }^{107}$

Eksport Malaysia ke Britain sehingga bulan April 1990 meningkat sebanyak 24 peratus bernilai kira-kira RM1.23 bilion, sementara import dari Britain pula meningkat sebanyak 41.6 peratus dengan jumlah sebanyak RM935 juta. Sektor utama yang mengalami peningkatan adalah pakaian dan aksesori pakaian meningkat sebanyak 76.5 peratus dengan jumlah RM101.5 juta. Kayu yang bergergaji sebanyak 67.3 peratus dengan jumlah RM87 juta dan peralatan telekomunikasi sebanyak 57 peratus dengan jumlah RM98.5 juta. ${ }^{108}$

Walau bagaimanapun eksport getah jatuh sebanyak 24 peratus dengan jumlah daripada RM83.5 juta kepada RM63.5 juta. Tekstil yarn dan fabrik jatuh sebanyak 19 peratus dengan jumlah dari RM18 juta kepada RM14.5 juta dan minyak sayur dan lemak jatuh 10.4 peratus dari RM48 juta kepada RM43 juta. Kejatuhan eksport Malaysia adalah kerana saingan hebat daripada negara-negara lain. ${ }^{109}$

Tindakan Dr. Mahathir mendapat perhatian daripada pihak Britain dan dibincangkan dalam mesyuarat kabinet Britain. Laporan kabinet menyatakan: "A worrying situation had arisen in Malaysia, where the new Prime Minister, Dr. Mahathir appear to harbor a grudge against Britain and to be trying to steer public sector contracts away from British bidders. This would need to be watched carefully."110

Melihat kepada kepentingan ekonomi Malaysia terhadap Britain, mereka perlu memberi perhatian yang sewajarnya bagi menangani isu-isu yang timbul tidak berlarutan. Menurut Faridah Jaafar, BBL boleh memberi kesan kepada aspek politik dan kerjasama antarabangsa. ${ }^{111}$

Terkejut dengan tindakan Malaysia dalam melaksanakan BBL, pihak Britain telah mengambil tindakan dengan melihat dan menilai semula rentak hubungan dengan Malaysia supaya dapat memperbaiki semula hubungan di antara kedua-dua negara. Menurut Mohd Yusof Ahmad, ia adalah satu tindakan untuk membebaskan Malaysia secara psikologi dan ekonomi daripada kesan penjajahan masa lalu yang terlalu bergantung kepada Britain. Dr. Mahathir juga mahu menterjemahkan dari sudut politik dan ekonomi bahawa Malaysia mahukan satu hubungan yang sama rata dengan Britain dan untuk mengimbangi sikap bias terhadap Barat pada masa lalu dengan Barat dan Timur. ${ }^{112}$

Pihak Britain juga telah turut mengambil inisiatif untuk berbaik semula dengan Malaysia. Ini telah membawa kepada meja perundingan dengan mengadakan satu pertemuan yang tidak rasmi kedua-dua pemimpin negara untuk berbincang masalah-masalah yang dihadapi oleh kedua-dua negara dan mencari jalan penyelesaian awal. Abdullah Ahmad menyatakan: "As a result in 1981 it had reached the point that something should be done to alter the situation." 113 


\section{Kesimpulan}

BBL adalah protes secara diplomatik yang dilaksanakan bagi memberitahu Britain bahawa Malaysia tidak lagi mahu menerima layanan yang kurang memuaskan dan perlunya dilakukan secara lebih tegas. Pada mulanya tindakan Mahathir dengan melaksanakan BBL tidak mendapat perhatian secara serius daripada pihak Britain. Usaha merapatkan hubungan diplomatik telah diusahakan oleh pihak Britain dengan menghantar beberapa pegawai untuk mendapatkan maklumat dan berharap dapat menyelesaikannya dengan segera. Mahathir tetap tegas dengan pendirian beliau dan mempertahankan perlaksanaan BBL. Apabila pihak Britain mula tertekan maka usaha yang lebih serius diambil. Satu pertemuan tidak rasmi telah diaturkan antara Mahathir dengan Margaret Thatcher di London. Pertemuan di antara keduadua pemimpin berlaku di pejabat Suruhanjaya Tinggi Malaysia di London. Setelah pertemuan kedua-dua pemimpin ini satu persetujuan telah dicapai dan Mahathir menamatkan BBL. Ini telah mengembalikan hubungan Malaysia dengan Britain secara saling hormat menghormati antara satu sama lain. Walaupun hubungan Malaysia dengan Britain telah pulih, namun terdapat beberapa isu perlu diselesaikan di meja rundingan. Usaha untuk memahami dan menyokong DEB telah diambil oleh pihak Britain dan tidak lagi memandang remeh terhadap DEB. Manakala, Malaysia tidak lagi memberi keistimewaan dan kelebihan kepada Britain. Pihak Britain perlu bersaing dengan negara-negara lain secara adil dalam mendapatkan kontrak di Malaysia.

Personaliti dan gaya kepimpinan Dr. Mahathir adalah berbeza daripada pemimpin lalu. Latar belakang dan pendidikan yang diterima oleh Dr. Mahathir adalah turut berbeza. Mahathir dikatakan tidak mempunyai nilai hubungan yang sentimental dengan Britain. Pemimpin-pemimpin lalu tidak membincangkan isu-isu secara terbuka. Ini berbeza dengan Dr. Mahathir yang bertindak agresif dan tegas dalam menangani beberapa isu telah membuatkan pihak Britain tidak lagi melihat beliau sebagai seperti pemimpin yang lalu. Dr. Mahathir telah berjaya membuatkan Malaysia tidak lagi menurut apa sahaja kemahuan Britain. Corak hubungan Malaysia dengan Britain adalah berbeza dan tidak berat sebelah. Pihak Britain tidak lagi dianggap istimewa seperti lalu, walaupun hubungan Malaysia dengan Britain terjalin begitu lama. Keberanian melaksanakan BBL telah membuatkan Britain terpaksa mengambil langkah untuk memulihkan hubungan dengan Malaysia kerana dari sudut perdagangan pihak Britain yang lebih banyak mengalami kerugian. Malaysia tidak lagi bergantung dengan Britain kerana terdapat banyak negara lain turut mahu melabur di Malaysia. Britain perlu bersaing dengan negara-negara lain secara adil.

Walaupun BBL telah ditamatkan tetapi hubungan sentimental Malaysia dengan Britain telah berubah. Wujudnya satu hubungan yang tidak berat sebelah dan perlunya saling menghormati antara kedua-dua negara. Britain tidak lagi memandang rendah terhadap Malaysia. Disebalik perlaksanaan BBL adalah suatu tindakan protes secara diplomatik terhadap Britain dan Malaysia mahukan satu pengiktirafan yang sama rata dan menghormati aspirasi Malaysia serta dihormati sebagai sebuah negara merdeka.

\section{Nota}

T. H. Silcock, 'The Development of Malayan Foreign Policy', dalamAustralian Outlook, Vol. 17, No. 1, Melbourne, April 1963; Joseph LiowChinyong, 'Vision Serumpun: Tun Abdul Razak and the Golden Years of Indo-Malay Blood Brotherhood, 1967-1975', dalamSoutheast Asia Research, Vol. 11, No. 3, November 2003, London: University of London; J. O. Sutter, 'Two Faces of Konfrontasi: 'Crush Malaysia' and the 'Gestapu', dalamAsian Survey, Vol. 6, No. 10, October 1966; Joseph M. Fernando, 
'The Formation of Malaysia: Shared History, Varied Images', dalamMalaysia In History, Vol. 29, 2005, Kuala Lumpur: PersatuanSejarah Malaysia, 2005.

2 J. Saravanamuttu, 'ASEAN in Malaysia Foreign Policy Discourse and Practice, 1967-1997', dalamAsian Journal of Political Science, Vol. 5, No. 1, June 1997.

3 MohamadRodziAbdRazak, 'PenyelesaianKonfrontasi Indonesia Malaysia 1966: IsudanKontroversi', dalamMaizatulHaizanMahbobdanMohamadZain bin Musa, (editor), TinjauanBaruPolitik Malaysia, Bangi: PenerbitUniversitiKebangsaan Malaysia, 2005; KhawGuatHoon, 'Dasar Malaysia terhadap persaingankuasa-kuasabesar di Asia Tenggara', dalamZurainaMajid, Masyarakat Malaysia: Edisi II, Pulau Pinang: PenerbitUniversitiSains Malaysia, 1985; Joseph Liow, 'Personality, Exigencies and Contingencies: Determinants of Malaysia's Foreign Policy in the Mahathir Administration', dalam Ho Khai Leong dan James Chin, Mahathir's Administration: Performance and Crisis in Government,

Singapore: Times Book International, 2001; Mohammed AzhariKarim (editor), Malaysia Foreign Policy: Issues on Perspectives, Kuala Lumpur: InstitutTadbiranAwam Negara Malaysia (INTAN), 1995; Rohani HjAbGhani, 'Perkecualian Asia Tenggara: LatarBelakangSejarah', dalamRadziahAbd Rahim (editor), Issues in International Affairs, Sintok: University Utara Malaysia Press, 2001; Bridget Welsh, (editor), Reflection: The Mahathir Years, Washington: Southeast Asia Studies Program, 2004, antaranya Lee Loh Ping, 'The Look East Policy, the Japanese Model and Malaysia'; Khadijah Md. Khalid, 'Malaysia-Japan Relations under Mahathir Turning Japanese?'.

4 J. Saravanamuttu, 'Iconoclasm and Foreign Policy - The Mahathir Years', dalam Bridget Welsh, (editor), Reflection: The Mahathir Years, Washington: Southeast Asia Studies Program, 2004, hlm. 307.

$5 \quad$ Roger Kershaw, 'Brown Humanity Strikes Back: Confronting Britain is a Good Cause?',dalam Bridget Welsh, (editor), Reflection: The Mahathir Years, hlm. 343.

6 Lee Poh Ping, 'The Look East Policy, The Japanese Model and Malaysia', dalam Bridget Welsh, (editor), Reflection: The Mahathir Years, Washington: Southeast Asia Studies Program, 2004, hlm. 318.

$7 \quad$ Khadijah Md Khalid dalam artikelnya yang bertajuk 'Malaysia-Japan relations under Mahathir: "Turning Japanese"?', dalam Bridget Welsh, (editor), Reflection: The Mahathir Years, Washington: Southeast Asia Studies Program, 2004, hlm. 325.

$8 \quad$ Rusdi Omar dan Muhammad Afifi Abdul Razak, 'Dasar Luar Malaysia dalam konteks hubungan Malaysia-Jepun', dalam Zulhilmi Paidi dan Asrar Omar, (editor), Hubungan Luar Antarabangsa, Bentong: PTS Publications \& Distributor Sdn Bhd, 2003, hlm. 141. Ibid., hlm. 133.

10 MohdAfendiDaud, DasarLuar Malaysia keatas Britain: Perbandingan di antara era Tunku Abdul RahmandenganTun Dr. Mahathir Mohamad, TesisSarjana, Kuala Lumpur: Universiti Malaya, 2008.

11 Khadijah Md. Khalid and Lee Poh Ping, Whither Look East policy, Bangi: PenerbitUniversitiKebangsaan Malaysia, 2003, hlm. 94.

12 Foreign Affairs Malaysia, September 1987, Vol. 20, No. 3, hlm. 60.

13 New Straits Times, 16 October, 1981, hlm. 2; Roger Kershaw, 'Brown Humanity Strikes Back:

Confronting Britain in a good cause?’ dalam Bridget Welsh (editor), Reflections: The Mahathir Years, hlm. $\quad 346$.

14 R.S. Milne and Diane K. Mauzy, Malaysian politics under Mahathir, London: Routledge, 1999, hlm. 139; Cheah Boon Kheng, Malaysia:The making of a nation, Singapore: Institute of Southeast Asian Studies, 2002, hlm. 207.

15 Kazuki Katayama, China's rise and Japan's Malaysia policy, Kuala Lumpur: University of Malaya Press, 2013, hlm. 15;Asiaweek, 30 October, 1981, hlm. 30-31; Jomo K. S., Warisanekonomi Mahathir, Kuala Lumpur: UtusanPubllications and Distributors SdnBhd, 2010, hlm. 43.

16 Ibid.; The Age, 02 August, 1982, hlm. 13, 'A blunt decisive nasionalist'.

17 Khoo Boo Teik, Paradoxes of Mahathirism: An intelectual biography of Mahathir Mohamad, Kuala Lumpur: Oxford University Press, 1995, hlm. 56.

18 Foreign Affairs Malaysia 1981, Vol. 14, hlm. 331.

19 Ibid.

20 Wan MohdMahyiddindanNikMustaffaYusof, Amanatpresiden: Landasanbagipembinaanbangsadan Negara, Jilid II, Shah Alam: PenerbitFajarBaktiSdnBhd, 1997, hlm. 323-324;Minit MesyuaratKhas, MengkajiImplikasiArahan YAB PerdanaMenteriMengenaiBekalandanKontrak Firma-Firma British pada 9 November 1981, Arkib Negara Malaysia, hlm. 5.

21 Firdaus Abdullah, 'The Prime Ministers of Malaysia', in Malaysian development experience: Changes and Challenges, Kuala Lumpur: National Institute of Public Administration, Malaysia, (INTAN), 1994, hlm. 321. 
BeritaHarian, 10 November, 1983,hlm. 4, 'Takadakaitandengan "Neo-kolonialisme”: Dr. M perjelaskan hubungankitadenganJepun'; FaridahJaafar, Perdanamenteridandasarluar Malaysia, 1957-2005, Kuala Lumpur: PenerbitUniversiti Malaya, 2007, hlm. 137. Ahmad AtoryHussain, Politikdandasarawam Malaysia, Kuala Lumpur: Utusan Publications and Distributors SdnBhd, 2002, hlm. 151.

Ibid.,hlm. 150-151.

Albert Kim Hoh, Mahathir and Malaysian modernization, Dissertation (M.A.), Kuala Lumpur: Universiti Malaya, 1999, hlm. 16.

MohdYusof Ahmad, Continuity and change in Malaysia's foreign policy, 1981-1986, Disertation Doctor of Philosophy, Massachusetts: Tutts University, 1990, hlm. 317.

FaridahJaafar, DasarLuarTunku Abdul RahmandanDasarLuar Mahathir Mohamad: Suatukajian komparatif, (tesis), IjazahDoktorFalsafah, Kuala Lumpur: Universiti Malaya, 2011, hlm. 145.

ShakilaParweenYacob (terjemahan), Nicholas J. White, Perniagaan British di Malaysia pascapenjajah 1957-70, 'Neokolonialisme' atau 'Pengunduran', Kuala Lumpur: InstitutTerjemahan Negara Malaysia, 2010, hlm. 79.

New Straits Times, 23 May, 2000, hlm. 12, 'Australia must know its place'; Karminder Singh Dhillon, Malaysian foreign policy in the Mahathir era 1981-2003: Dilemmas of development, Singapore: NUS Press, 2009, hlm. 167.

Karminder Singh Dhillon, Malaysian foreign policy in the Mahathir era 1981-2003: Dilemmas of Development,hlm. 172.

CAB128/71/03, MesyuaratKabinet Britain.

MaklumBalasBerkenaandenganefekreaksi British terhadapdasarkerajaanmengenaibekalandan kontrek firma-firma British, Arkib Negara Malaysia, hlm. 4.

Karminder Singh Dhillon, Malaysian foreign policy in the Mahathir era 1981-2003: Dilemmas of Development, hlm. 172.

BahagianPerdaganganAntarabangsa, KementerianPerdagangandanPerindustrian, Arkib Negara Malaysia.

Ibid.;Ahmad AtoryHussain, Politikdandasarawam Malaysia,hlm. 148.

Ibid.

Foreign Affairs Malaysia, June 1985, Vol. 18, No. 2, hlm. 88.

Ibid.

R.S. Milne and Diane K. Mauzy, Malaysian politics under Mahathir,hlm. 139; MohdYusof Ahmad, Continuity and change in Malaysia's foreign policy, 1981-1986, hlm. 318.

New Straits Times, 3 October, 1981, hlm. 1, 'British goods - Malaysia act'.

SuratPekeliling Am Sulit, Bil. 4 Tahun 1981; Roger Kershaw, 'Brown Humanity Strikes Back:

Confronting Britain in a good cause?' dalam Bridget Welsh (editor), Reflections: The Mahathir Years,hlm. 347; $\quad$ Karminder Singh Dhillon, Malaysian foreign policy in the Mahathir era 1981-2003: Dilemmas of Development,hlm. 160-161; New Straits Times, 3 October, 1981, hlm. 1, 'British goods-Malaysia act'; $\quad$ Khoo Boo Teik, Paradoxes of Mahathirism: An intelectual biography of Mahathir Mohamad, hlm. 55.

MohdYusof Ahmad, Continuity and change in Malaysia's foreign policy, 1981-1986, hlm. 318.

Ibid.,hlm. 317.

New Straits Times, 9 October, 1981, hlm. 2, 'Tender award: British to play it cool for a while'. Asiaweek, 30 October, 1981, hlm. 26.

New Straits Times, 3 October, 1981, hlm. 1, 'British goods - Malaysia act'.

MinitMesyuaratKhas, MengkajiImplikasiArahan YAB PerdanaMenteriMengenaiBekalandanKontrak

Firma-Firma British pada 9 November 1981, Arkib Negara Malaysia, hlm. 4.

Ibid.

Ibid.

Foreign Affairs Malaysia, 1981, Vol. 14, hlm. 331; MinitMesyuaratKhas, MengkajiImplikasiArahan

YAB PerdanaMenteriMengenaiBekalandanKontrak Firma-Firma British pada 9 November 1981, Arkib Negara Malaysia, hlm. 3.

The Glasgow Herald, 22 Oktober, 1981, hlm. 13, 'Malaya tightens up on contracts'.

Ibid.

New Straits Times, 16 October, 1981, hlm. 1, 'British traders keen to restore goodwill'.

Ibid.,27 October, 1981, hlm. 1, 'We'll not buy British if we can help it'. 
MinitMesyuaratKhas, MengkajiImplikasiArahan YAB PerdanaMenteriMengenaiBekalandanKontrak Firma-Firma British pada 9 November 1981, Arkib Negara Malaysia, hlm. 3; The Glasgow Herald, 9 Februari, 1982, hlm.6, 'Failure of a mission'. Malaysian Business, January 1982, hlm. 34; New Straits Times, 27 October, 1981, hlm. 1; 'We'll not buy British if we can help it'.

57 Suratbertarikh 2 November 1981, rujukan PM (R) 11880/A/800.

58 MinitMesyuaratKhas, MengkajiImplikasiArahan YAB PerdanaMenteriMengenaiBekalandanKontrak Firma-Firma British pada 9 November 1981, Arkib Negara Malaysia, hlm. 2; Ahmad AtoryHussain, Politikdandasarawam Malaysia, hlm. 150.

MaklumBalasBerkenaandenganefekreaksi British terhadapdasarkerajaanmengenaibekalandan kontrek firma-firma British, Arkib Negara Malaysia, hlm. 4. Ibid.;Johan Saravanamuttu, Malaysia's Foreign Policy: The First Fifty years: Alignment, Neutralise, Islamism, Singapore: Institute of Southeast Asian Studies, 2010, hlm. 187.

Ibid.

Ibid.

63 Khadijah Md. Khalid and Lee Poh Ping, Whither the Look East policy, hlm. 115; FaridahJaafar, Dasar LuarTunku Abdul RahmandanDasarLuar Mahathir Mohamad: SuatukajianKomparatif, hlm. 146.

MaklumBalasBerkenaandenganefekreaksi British terhadapdasarkerajaanmengenaibekalandan kontrek firma-firma British, Arkib Negara Malaysia, hlm. 5.

Khadijah Md. Khalid, 'Malaysia-Japan relations under Mahathir: “Turning Japanese"?' dalam Bridget Welsh, (editor), Reflections: the Mahathir years, Washington: Southeast Asia Studies Program, 2004, hlm. 324; Johan Saravanamuttu, Malaysia's Foreign Policy: The First Fifty years: Alignment, Neutralise, Islamism, hlm. 187.

MaklumBalasBerkenaandenganefekreaksi British terhadapdasarkerajaanmengenaibekalandan

kontrek firma-firma British, Arkib Negara Malaysia, hlm. 5.

Ibid.

Ibid.

Ibid.

Ibid.,hlm. 10.

BeritaMinggu, 19 Julai, 1987, hlm. 8.

Foreign Affairs Malaysia, June 1985, Vol. 18, No. 2, hlm. 104.

Malaysian Business, May 1983, hlm. 87.

Surat JPM, bertarikh 31 Mac 1983, PM. (R) 11880/A/800; New Straits Times, 4 April, 1983, hlm.1, 'Britain happy with Dr. M's decision'.

New Straits Times, 4 April, 1983, hlm. 1, 'Britain happy with Dr. M's decision'; Barry Wain, Malaysian Maverick: Mahathir Mohamad in turbulent times, United Kingdom: Palgrave Macmillan, 2009, hlm. 249. Ibid.

79 Foreign Affairs Malaysia, September 1987, Vol. 20, No. 3, hlm. 60.

80 Utusan Malaysia, 11 Ogos, 1987, hlm.4, 'Ada pihak tabor tohmahuntuktakutkanpelabur Britain - PM; Apabila Dr. Mahathir ditanyaolehwartawansiapakahpihaktertentutersebut. Dr. Mahathir menjawab: "Terpulanglahkepadasaudarauntukmeintepretasikannya." MinitMesyuaratKhas, MengkajiImplikasiArahan YAB PerdanaMenteriMengenaiBekalandanKontrak Firma-Firma British pada 9 November 1981, Arkib Negara Malaysia, hlm. 2. New Straits Times, 16 October, 1981, hlm. 3, 'Ghaz: Emergence of 'ugly attitude' on part of Britain'. Foreign Affairs Malaysia 1981, Vol. 14, hlm. 331.

New Straits Times, 16 October, 1981, hlm. 1, 'UK firms furious over Times report'.

MinitMesyuaratKhas, MengkajiImplikasiArahan YAB PerdanaMenteriMengenaiBekalandanKontrak Firma-Firma British pada 9 November 1981, Arkib Negara Malaysia, hlm. 3.

$86 \quad$ Foreign Affairs Malaysia 1981, Vol. 14, hlm. 331.

87 MinitMesyuaratKhas, MengkajiImplikasiArahan YAB PerdanaMenteriMengenaiBekalandanKontrak Firma-Firma British pada 9 November 1981, Arkib Negara Malaysia, hlm. 3.

Ibid.hlm. 4.

Ibid.

MohdYusof Ahmad, Continuity and change in Malaysia's foreign policy, 1981-1986,hlm. 318.

Ibid.,hlm. 319; Barry Wain, Malaysian maverick: Mahathir Mohamad in turbulent times, hlm. 249. Ibid. 
Cheong Mei Sui danAdibah Amin, Daim: Insan di sebalik enigma, Petaling Jaya: Pelanduk Publications, 1996, hlm. 86; Syarikat asinghanyabolehmemiliki paling maksimumekuitisebanyak 49 peratus.

Foreign Affairs Malaysia, March 1987, Vol. 20, No. 1, hlm. 64; Khoo Boo Teik, Paradoxes of Mahathirism: An intelectual biography of Mahathir Mohamad,hlm. 140; EIR, Volume 13, No. 41, October 17, 1986, hlm. 9; Cheong Mei Sui danAdibah Amin, Daim: Insan di sebalik enigma,hlm. 87. Foreign Affairs Malaysia, September 1987, Vol. 20, No. 3, hlm. 61; Cheong Mei Sui danAdibah Amin, Daim: Insan di sebalik enigma, hlm. 88.

96 Foreign Affairs Malaysia, June 1985, Vol. 18, No. 2, hlm. 88.

$97 \quad$ PenyataRasmiParlimen, Dewan Rakyat, 5 November, 1985, hlm. 6300.

98 The New Straits Times, 4 April, 1983, hlm. 1; 'Britain happy with Dr. M's decision'.

99 MaklumBalasBerkenaandenganefekreaksi British terhadapdasarkerajaanmengenaibekalandan kontrek firma-firma British, Arkib Negara Malaysia, hlm. 5.

100 Ahmad AtoryHussain, Politikdandasarawam Malaysia, hlm. 151.

101 Foreign Affairs Malaysia, September 1987, Vol. 20, No. 3, hlm. 51.

102 Ibid.;Ucapan di London pada 23hb Julai 1987 sempenamakantengaharidikendalikanolehKonfendrasi Industri British.

103 Ibid

104 BeritaMinggu, 19 Julai, 1987, hlm. 8.

105 Ibid.

106 Utusan Malaysia, 1 Disember, 1990, hlm.26, 'Eropahketinggalan di belakang Taiwan danJepun Rafidah'.

107 New Straits Times, 25 August, 1990, hlm. 17, 'Trade with Britain heading for record high'.

108 Ibid.

109 Ibid

$110 \quad C A B 128 / 71 / 14,29$ October, 1981, MesyuaratKabinet Britain, hlm. 1.

111 FaridahJaafar, Perdanamenteridandasarluar Malaysia, 1957-2005, Kuala Lumpur: PenerbitUniversiti Malaya, 2007, hlm. 137.

112 MohdYusof Ahmad, Continuity and change in Malaysia's foreign policy, 1981-1986, hlm. 317.

113 New Straits Times, 23 May, 2000, hlm. 12, 'Australia must know its place'. 